\title{
Perlindungan Hukum bagi Konsumen terhadap Transaksi Jual Beli E-Commerce
}

\author{
Yudha Sri Wulandari \\ Program Studi Ilmu Hukum, Universitas Kutai Kartanegara, Tenggarong. \\ Email : yudha.sriwulandari80@gmail.com
}

\section{Info Artikel:}

| Diterima: 10 Agustus 2018

| Disetujui: 29 Desember 2018

| Dipublikasikan: 31 Desember 2018

\begin{abstract}
Behind the rapid advances in technology, especially the development of the Internet in Indonesia, there are a lot of negative things being targeted and harassed people who like the Internet that we usually hear as Internet surfers. For business and trade in the internet media is required understanding, seriousness, and the will of its own. In an agreement is often one of the parties / stakeholders have to face difficult conditions and ultimately contact / agreement that has been agreed can not walk / run well / as appropriate. Factors that make it difficult events that can occur due to deliberate or accidental. Default is a condition / situation that can be done by one of the parties or the parties to an engagement which can be generally described that the treaty was not executed properly and not in accordance with what has been agreed from the beginning. Plunge into the business of buying and selling online / transact electronically (e-commerce) is a rare move but it's a lifestyle and trend in this medern era, but must also watch out and be noticed. Among the things that can later be referred to as a form of default. Default in the purchase agreement online can take many forms and sometimes we experienced it and still not sensitized that this / these events can be called an act of default. For example: late payment, no payment, send the goods but not in accordance with what was agreed, but too late to send goods, which in turn raises certain legal consequences. Keywords: liability, breach of contract, buying and selling online.
\end{abstract}

Keywords: liability, breach of contract, buying and selling online.

\begin{abstract}
Abstrak
Dibalik pesatnya kemajuan tekhnologi khususnya perkembangan internet di Indonesia, ternyata terdapat banyak hal negatif yang mengincar dan sedang mengganggu para orang yang menyukai internet yang biasa kita dengar dengan sebutan peselancar internet. Untuk berbisnis dan bertransaksi dalam media internet diperlukan pemahaman, keseriusan, dan kemauan tersendiri. Dalam suatu perjanjian seringkali salah satu pihak/para pihak harus menghadapi kondisi yang sulit dan pada akhirnya kontak/perjanjian yang telah disepakati tidak bisa berjalan/dijalankan dengan baik sebagai mana mestinya. Faktor-faktor yang membuat kejadian-kejadian sulit itu bisa terjadi karena kesengajaan maupun ketidaksengajaan. Wanprestasi adalah suatu keadaan/situasi yang dapat dilakukan oleh salah satu pihak atau para pihak dalam suatu perikatan yaitu secara umum dapat digambarkan bahwa isi perjanjian tersebut tidak dijalankan dengan baik dan tidak sesuai dengan apa yang telah disepakati dari awal. Terjun langsung kedalam bisnis jual beli secara online/bertransaksi secara elektronik (e-commerce) merupakan suatu tindakan yang jarang dilakukan akan tetapi sudah menjadi gaya hidup dan trend pada era modern ini, namun harus juga diwaspadai dan diperhatikan. Diantaranya hal-hal yang nantinya dapat disebut sebagai bentuk wanprestasi. Wanprestasi dalam perjanjian jual beli secara online mempunyai banyak bentuk dan terkadang kita mengalaminya namun masih belum peka bahwa hal/kejadian tersebut dapat disebut suatu tindakan wanprestasi. Misalnya: keterlambatan membayar, tidakmelakukan pembayaran, mengirim barang namun tidak sesuai dengan apa yang disepakati, mengirim barang namun terlambat, yang nantinya menimbulkan akibat hukum tertentu.
\end{abstract}

Kata kunci: tanggunggugat, wanprestasi, jualbeli online. 


\section{A. PENDAHULUAN}

Pesatnya pertumbuhan teknologi
informasi dan sistem transaksi secara
elektronik telah menjadikan industri teknologi
informasi menjadi industri yang diunggulkan.
Selain memberikan kemudahan dan efisiensi
waktu, teknologi informasi juga memberikan
keuntungan yang lainnya, yaitu untuk
memperluas pangsa pasar ke seluruh dunia
tanpa harus pergi atau mengirim orang ke
negara-negara lain untuk memasarkannya.

Dengan pemanfaatan teknologi tersebut telah banyak memberikan kemudahan bagi manusia dalam melaksanakan pekerjaan sehari-hari. Sebagai contoh yaitu dalam dunia perdagangan, di dalam melakukan transaksi bisnis seorang pembeli tidak mesti bertatapan langsung dengan penjual seperti layaknya dalam pasar tradisional melainkan hanya melalui suatu media elektronik yang terhubung secara online, yang dikenal dengan internet. Sekarang ini di dunia bisnis dikenal ada dua model utama, yaitu bisnis konvensional yang merujuk kepada nilai dan tata cara yang tradisional, yang lazim dikenal dengan bisnis klasik atau konvensional, dan bisnis modern yang bersifat kontemporer. Masing-masing model bisnis memiliki cara, permasalahan, konsekuensi yuridis, dan solusi yang berbeda.

Salah satu hasil perkembangan teknologi informasi adalah jual beli yang dilakukan melalui media elektronik dan dikenal dengan kontrak jual beli secara elektronik. Berdasarkan sumber hukum di Indonesia, suatu kontrak jual beli harus memiliki beberapa klausula-klausula yang tekstual, yaitu berbentuk akta atau kontrak secara tertulis, jelas, dan nyata, baik berupa akta otentik maupun akta dibawah tangan. Hal ini akan mempermudah pelaksanaan kontrak jual beli termasuk hak dan kewajiban dari para pelakunya.

Sistem hukum yang berlaku saat ini yang belum mempertimbangkan pengaruhpengaruh dari pemanfaatan internet. Sedangkan bisnis modern yang bersifat kontemporer sudah dipengaruhi oleh pemanfaatan dari internet. Perkembangan yang paling mutakhir muncul sebuah model atau sistem transaksi bisnis yang sangat inovatif dan kreatif mengikuti high tehc improvement (kemajuan teknologi tinggi) di bidang komunikasi dan informasi. Canggihnya teknologi modern saat ini dan terbukannya jaringan informasi global yang serba transparan. Hal ini ditandai dengan kemunculan internet, cybernet, atau word wide web $(w w w)$ yakni sebuah teknologi yang memungkinkan adanya transformasi informasi secara cepat keseluruh dunia maya. ${ }^{1}$

Dengan teknologi internet semacam ini, human action (prilaku manusia), human interaction (interaksi antar manusia) dan human relation (hubungan manusia mengalami perubahan yang cukup signifikan khususnya di dalam hubungan dagang atau bisnis). Bisnis teknologi informasi seperti ini dikenal dengan istilah Electronic commerce atau electronic bussiness. E-commerce (perniagaan teknologi), sebagai bagian dari $e$ business (bisnis yang dilakukan dengan menggunakan electronic transmission, oleh para ahli dan pelaku bisnis dicoba dirumuskan definisinya dari terminologi e-commerce (perniagaan elektronik). Secara umum $e$ commerce dapat didefinisikan sebagai segala bentuk transaksi perdagangan/perniagaan barang atau jasa (trade of goods and service) dengan menggunakan media elektronik.

Kontrak jual beli secara elektronik ini cenderung menggunakan sistem hukum yang mengacu kepada norma atau kaidah yang berlaku pada suatu negara, termasuk di Indonesia. Berdasarkan ketentuan hukum jual beli yang berlaku ada beberapa hal yang bersifat essensial dalam proses jual beli, yaitu mengenai hak dan kewajiban para pelakunya dalam melakukan kontrak jual beli yang ditegaskan pada saat adanya kesepakatan jual

\footnotetext{
${ }^{1}$ Muhammad Arsyad Sanusi, Transaksi Bisnis dalam E-comerce: Studi Tentang Permasalahan Hukum dan Solusinya, dalam Jurnal Hukum Ius Quia Iustum, No. 16 Vol. 8 Maret 2001: 10-29, (Jakarta: Fakultas Hukum Universitas Islam Indonesia, 2001).
} 
beli sebagai pendukung keabsahan pembuktian dari suatu perjanjian jual beli tersebut.

Ada beberapa keuntungan yang dapat diperoleh dengan menggunakan internet sebagai media perdagangan, yaitu:

1) Keuntungan bagi pembeli:

a) menurunkan harga jual produk;

b) meningkatkan daya kompetisi penjual;

c) meningkatkan produktivitas pembeli;

d) manajemen informasi yang lebih baik;

e) mengurangi biaya dan waktu pengadaan barang;

f) kendali inventory yang lebih baik.

2) Keuntungan bagi penjual:

a) identifikasi target pelanggan dan definisi pasar yang lebih baik;

b) manajemen cash flow yang lebih baik;

c) meningkatkan kesempatan berpartisipasi dalam pengadaan barang atau jasa (tender);

d) meningkatkan efisiensi;

e) kesempatan untuk melancarkan proses pembayaran pesanan barang;

f) mengurangi biaya pemasaran.

Dengan sistem e-commerce ini seorang penjual (seller) tidak harus bertemu langsung (face to face) dengan pembeli (buyers/consumers), dalam suatu transaksi dagang. Transaksi bisa terjadi hanya lewat surat menyurat melalui e-mail, telekopi dan lain-lain. Pembayaran (payment) bisa dilakukan juga melalui internet. ${ }^{2}$ Data message (pesan data) yang berisi aggrement (perjanjian dan kesepakatan kontrak) bisa disampaikan oleh salah seorang diantara pihak yang terkait (sebagai originator) kepada pihak lain (si penerima, addressee) secara langsung atau melewati mediator (intermediary) melalui jasa elektronik seperti internet, ekstranet, email dan lainnya. ${ }^{3}$ Menurut Bajjaj dalam bukunya yang berjudul E-commerce: The cutting edge of business menyebutkan sejumlah keuntungan

\footnotetext{
${ }^{2}$ Riyeke Ustadiyanto, Framework E-Commerce, Andi,Yogyakarta. 2001,Hal. 138

${ }^{3}$ M. ArsyadSanusi, Op Cit, Hal. 30
}

(advantage) yang bisa diperoleh dari $e$ commerce ini, antara lain :

1. Penghematan waktu;

2. Mengurangi kemungkinan melakukan kesalahan dalam pengetikan dan sebagainya karena sudah disiapkan model standar yang tidak pernah diketik ulang; dan

3. Karena waktu bisnis dapat digunakan seefisien mungkin, maka sangat memungkinkan untuk mendapat lebih banyak informasi mengenai bisnisnya sehingga menunjang efektivitas dan efesiensi suatu perusahaan atau bisnis. $^{4}$

Terlepas dari keuntungan yang ditawarkan oleh e-commerce tersebut di atas, terdapat pula permasalahan-permasalahan hukum yang sangat krusial. Kalau dilihat dari proses dan mekanisme terjadinya transaksi dapat dikemukakan beberapa permasalahan hukum sehubungan dengan masalah kontrak atau perjanjian antara lain sebagai berikut :

1. Masalah kapan terjadinya atau lahirnya kesepakatan dalam transaksi $e$ commerce Permasalahan ini erat kaitannya dengan saat bertemunya permintaan dan penawaran melalui media maya tersebut;

2. Masalah pilihan hukum dan masalah pembuktian; dan

3. Masalah keabsahan digital signature dan data message.

Permasalahan di atas menunjukkan bahwa dalam beberapa segi, transaksi dalam e-commerce sangat riskan, penuh resiko, terlebih karena pihak konsumen memiliki kewajiban melakukan pembayaran terlebih dahulu (advance payment) sementara ia tidak bisa melihat kebenaran adanya barang yang dipesan ataupun kualitasnya. Pembayaran yang dilakukan secara elektronik baik melalui

\footnotetext{
${ }^{4}$ Pramono, Nindyo, 2001, Revolusi Dunia Bisnis Indonesia Melalui E-commerce dan E-Bussines: Bagaimana solusi hukumnya, Artikel Dalam Jurnal Hukum No. 16 Vol. 8/2001, Universitas Islam Indonesia, Jakarta.R.M. Suryodiningrat, 1979, AzasAzas Hukum Perikatan, Tarsito, Bandung. Hal. 15
} 
transfer bank atau, lewat pengisian nomor kartu kredit di dalam internet sangat membuka peluang terjadinya kecurangan perdata dan pidana, sementara belum ada jaminan pasti (exact guaranteed) bahwa barang yang dipesan telah dikirimkan sesuai dengan pesanan. Apakah yang menjadi alat bukti ketika nantinya terdapat gugatan hukum, dasar apakah yang digunakan untuk menilai keotentikan sebuah dokumen elektronik dalam e-commerce yang rata-rata tidak memiliki tanda-tangan (signature). ${ }^{5}$ Kemudian, berdasarkan ketentuan Pasal 1 Angka 10 Undang-Undang Nomor 11 Tahun 2008 tentang Informasi dan Transaksi Elektronik, disebutkan bahwa transaksi elektronik adalah perbuatan hukum yang dilakukan dengan menggunakan komputer, jaringan komputer atau media elektronik lainnya.

Pada transaksi jual beli secara elektronik, sama halnya dengan transaksi jual beli biasa yang dilakukan di dunia nyata, dilakukan oleh para pihak yang terkait, walaupun dalam jual beli secara elektronik ini pihak-pihaknya tidak bertemu secara langsung satu sama lain, tetapi berhubungan melalui internet. ${ }^{6}$

Dalam transaksi jual beli secara elektronik, pihak-pihak yang terkait antara lain:

1. Penjual atau merchant sebagai pelaku usaha;

2. Pembeli atau konsumen

3. Bank sebagai pihak penyalur dana dari pembeli atau konsumen kepada penjual atau pelaku usaha/merchant.

4. Providersebagai penyedia jasa layanan akses internet.

Berdasarkan pada uraian diatas maka permasalahan yang akan dibahas dalam penelitian ini yaitu hubungan hukum antara pihak dalam transaksi jual beli barang melalui e-commerce. Serta Bagaimana tanggung

${ }^{5}$ M. ArsyadSanusi, Op Cit, Hal: 12

${ }^{6}$ Edmon Makarim,. 2000, Kompilasi Hukum

Telematika, Grafindo Persada, Jakarta. Hal. 65 gugat distributor dalam hal terjadi wanprestasi. Oleh karena itu, penelitian ini menggunakan pendekatan yuridis normatif yang mencoba menelaah hubungan antara para pihak dalam bertransaksi elektronik berkenaan dengan perselisihan wanprestasi.

\section{B. METODE PENELITIAN}

Untuk mendapatkan data yang diperlukan dalam penelitian ini, maka penulis menggunakan metode pengumpulan data, yakni: Penelitian Kepustakaan (library research). Sehubungan dengan permasalahan dalam penelitian ini maka pengumpulan data akan dilakukan melalui Penelitian Kepustakaan, dikumpulkan melalui penelitian literatur, yakni dengan mempelajari ketentuan Perundang-undangan tentang Transaksi Ecommerce dan Peraturan Perundangundangan lain yang relevan dengan materi penelitian.

\section{KERANGKA KONSEPSIONAL}

Berbisnis dan bertransaksi dalam media internet diperlukan pemahaman, keseriusan, dan kemauan tersendiri. Kejelian dan kepekaan lebih dalam mengenai lawan bisnis ataupun aplikasi atau situs yang kita jumpai di internet, apakah lawan bisnis kita sehat? Dan apakah situs atau aplikasi yang kita pilih aman dan bukan bajakan? Karena apabila kita lengah atau kurang peka maka bukan tidak mungkin kita akan menjadi korban dalam bisnis online baik berupa Wanprestasi maupun bentuk penipuan yang berujung pada tindak pidana. Namun disisi lain banyak orang yang sudah mulai menggunakan internet bukan hanya sebagai tempat untuk mencari berita atau informasi tentang hal apapun saja, akan tetapi orangorang sudah mencari penghasilan.

Dengan menjamurnya situs jual beli online maka baik secara langsung ataupun tidak langsung telah berdampak besar pada perkembangan dan pertumbuhan ekonomi nasional. Namun adakalanya, baik pihak penjual ataupun pihak pembeli kurang memahami tata cara berbisnis yang baik 
terutama melalui internet. Maksudnya, mereka terkadang kurang memahami bagaimana arti serta apa yang harus dilakukan untuk mengatasinya? Seperti apa bentuknya? Serta apa yang harus dilakukan untuk mengatasinya? Karena memang tidak semua dari mereka berlatar belakang pendidikan dari sekolah bisnis, hukum atau ekonomi dan tidak semua dari mereka mempunyai jenjang pendidikan yang sama. Untuk itu, pemerintah seyogyanya memberikan pengawasan dengan mewajibkan diadakannya suatu pendaftaran terhadap segala kegiatan yang menyangkut kepentingan umum. Termasuk di dalamnya, pendaftaran atas usaha-usaha elektronik $(e-$ business) yang berupa virtual shops ataupun virtualservices lainnya.diharap kan dapat tercapai suatu kepastian hukum. Namun kita pun harus menyadari, internet sebagai suatu dunia maya yang bersifat borderless, tanpa adanya suatu pemegang otoritas tertinggi di dalamnya, tentu akan sangat sulit untuk diregulasi.

\section{PEMBAHASAN}

\section{Hubungan Hukum Para Pihak Dalam Transaksi Jual Beli Barang melalui Electronic Commerce}

Secara umum e-commerce dapat didefinisikan sebagai segala bentuk transaksi perdagangan / perniagaan barang atau jasa (trade of goods and service) dengan menggunakan media elektronik yang terhubung secara online yang dikenal dengan internet, kegiatan perniagaan tersebut merupakan bagian dari kegiatan bisnis ${ }^{7}$.

Penggunaan internet dipilih oleh kebanyakan orang sekarang ini karena kemudahan-kemudahan yang dimiliki jaringan internet :

a. Internet sebagai jaringan publik yang sangat besar, layaknya yang dimiliki suatu jaringan publik elektronik, yaitu murah, cepat dan kemudahan akses.

\footnotetext{
${ }^{7}$ Munir Fuady,. 2001, Hukum Kontrak: Dari sudut Pandang Hukum Bisnis, Buku Pertama,Citra Aditya Bakti. Jakarta. Hal. 34
}

b. Menggunakan data elektronik sebagai media penyimpanan pesan atau data sehingga dapat dilakukan pengiriman dan penerimaan informasi secara mudah dan singkat, baik dalam bentuk data elektronik, analog, maupun digital. ${ }^{8}$

Berbeda dengan transaksi perdagangan biasa, transaksi e-commerce memiliki beberapa karakteri khusus yakni :

a. Transaksi tanpa batas

b. Transaksi anonim

c. Produk digital dan non digital

d. Produk yang tak berwujud

Sebagaimana yang terjadi dalam perdagangan di dunia nyata, basis hukum utama untuk transaksi e-commerce adalah kontrak. Kontrak di sini menyangkut bisnis ke bisnis dan bisnis ke konsumen. Kontrak online di dalam transaksi internet memiliki beberapa variasi diantaranya adalah: ${ }^{9}$

a. Kontrak pengembangan dan pengaturan jaringan elektronik (website desig and development contract)

b. Kontrak melalui chatting dan video conference

c. Kontrak pengadaan pembayaran dengan kartu kredit

d. Kontrak melalui email.

Praktek e-commerce yang berkembang begitu cepat seperti yang kita rasakan sekarang ini sayangnya tidak disertai dengan pembangunan landasan hukum yang secara khusus mengatur e-commerce sehingga bisa dijadikan pegangan demi terciptanya suatu kepastian hukum. Terlepas dari hal di atas terdapat beberapa keuntungan e-commerce bagi kepentingan organisasi, individu dan masyarakat. Keuntungan untuk organisasi diantaranya yaitu dengan adanya $e$-commerce

\footnotetext{
${ }^{8}$ Ridwan Khairandy,. 2003, Itikad Baik dalam Kebebasan Berkontrak, Universitas Indonesia Fakultas Hukum Pasca Sarjana, Jakarta. Hal. 42 ${ }^{9}$ Nandang Sutrisno,. 2001, Cyberlaw: Problem dan Prospek Pengaturan Aktifitas Internet,dalam Jurnal Hukum Ius Quies Justum, No. 16 Vol. 8 Maret 2001:, Fakultas Hukum Universitas Islam Indonesia, Jakarta. Hal. 10-29
} 
dapat memperluas tempat pemasaran untuk pasar nasional dan internasional.

\section{Hak Dan Kewajiban Para Pihak}

Pada penjualan, kontrak dan kesepakatan terbatas pada hal-hal yang berhubungan dengan penjualan barang-barang pada masa kini dan masa yang akan datang, dan kontrak penjualan meliputi sebuah transaksi penjualan pada saat ini serta kontrak penjualan pada masa yang akan datang ${ }^{10}$.

Dalam kontrak jual beli para pelaku yang terkait didalamya mempunyai hak dan kewajiban yang berbeda, kewajiban penjual dalam suatu perjanjian jual beli, sebagai berikut : Menyerahkan hak millik atas barang yang diperjual-belikan.Kewajiban menanggung kenikmatan tentram dan menanggung cacat-cacat tersembunyi (vrijwaring, warranty). Hak penjual pada umumnya menentukan harga pembayaran atas penjualan barang dari konsumen. Hak menerima pembayaran yang sesuai dengan kesepakatan mengenai kondisi dan nilai tukar barang dan/atau jasa yang diperdagangkan.Hak untuk mendapatkan perlindungan hukum dari tindakan konsumen yang beritikad baik. Hak untuk melakukan pembelaan diri sepatutnya di dalam penyelesaian hukum sengketa konsumen. Hak untuk rehabilitasi nama baik apabila tidak terbukti secara hukum bahwa kerugian konsumen tidak berakibat oleh barang dan/atau jasa yang diperdagangkan. Hak-hak yang diatur dalam ketentuan peraturan perundang-undangan lainnya. Hak pembeli dalam suatu proses jual beli pada umumnya, dibagi 2 (dua) macam, yaitu :

Pemindahan hak atas barang tertentu. Hak atas barang tertentu berpindah tergantung dari keinginan para pihak berdasarkan suatu perjanjian yang dibuat, dan untuk menentukan maksud dari para pihak tersebut, dengan

${ }^{10}$ M. ArsyadSanusi,TransaksiBisnisdalam E-comerce: StudiTentangPermasalahanHukum dan Solusinya, dalamJurnalHukumIusQuiaIustum, No. 16 Vol. 8 Maret 2001: (Jakarta: FakultasHukumUniversitas Islam Indonesia, 2001). Hal. 38. memperhatikan dalam suatu syarat-syarat perjanjian. Berdasarkan Pasal 1 UU No. 8 tahun 1999 tentang Perlindungan konsumen, Pembeli dianggap sebagai konsumen sehingga berdasarkan Pasal 4 UU No. 8 Tahun 1999 tentang Perlindungan Konsumen hak pembeli atau hak konsumen antara lain :

1. Hak atas kenyamanan, keamanan, dan keselamatan dalam mengkonsumsi barang dan/atau jasa ;

2. Hak untuk memilih barang dan/atau jasa serta mendapatkan barang dan/atau jasa tersebut sesuai dengan nilai tukar dan kondisi serta jaminan yang dijanjikan.

Hak yang diberikan kepada konsumen (pembeli), harus diimbangkan dengan kewajiban yang diberikan kepada konsumen agar konsumen tidak sewenang-wenang dalam melakukan tindakannya, maka hak-hak tersebut dibatasi.

Kewajiban konsumen sebagaimana diatur dalam Pasal 5 UU No. 8 tahun 1999 tentang Perlindungan Konsumen, adalah : Membaca atau mengikuti petunjuk informasi dan prosedur pemakaian atau pemanfaatan barang dan/atau jasa, demi keamanan dan keselamatan; Beritikad baik dalam melakukan transaksi pembelian barang dan/atau jasa; Membayar sesuai dengan nilai tukar yang disepakati; Mengikuti upaya penyelesaian hukum sengketa perlindungan konsumen secara patut.

Kewajiban konsumen untuk membaca atau mengikuti petunjuk dalam menggunakan barang dan/atau jasa terkadang dilalaikan oleh konsumen, biasanya pelaku usaha telah mencantumkan petunjuk pemakaian di dalam produk yang dibuatnya. Dalam pelaksanaan kontrak jual beli, adanya itikad baik merupakan hal yang harus dimiliki oleh para pihak. Legalitas atau keabsahan dari suatu kontrak atau perjanjian khususnya dalam kontrak jual beli secara elektronik menjadi sebuah fenomena yuridis yang relatif baru bagi hukum positif Indonesia pada umumnya. Hal ini perlu dikaji lebih lanjut terhadap aspek hukum pembuktian pada khususnya. 
Proses pembuktian terhadap suatu peristiwa dapat dilakukan dengan beberapa cara. Menurut Paton dalam bukunya $A$ Textbook Of Jurisprudence disebutkan bahwa, alat bukti dapat bersifat oral, documentary, atau materiil, alat bukti yang bersifat oral merupakan kata-kata yang diucapkan seorang dalam pengadilan, artinya kesaksian tentang suatu peristiwa merupakan alat bukti yang bersifat oral, alat bukti yang bersifat documentary adalah alat bukti yang surat atau alat bukti tertulis, sedang alat bukti yang bersifat materiil adalah alat bukti barang fisik yang tampak atau dapat dilihat selain dokumen ${ }^{11}$.

\section{Perlindungan Hukum Para Konsumen}

Salah satu kelebihan atau keuntungan dalam e-commerce adalah informasi yang beragam dan mendetail yang dapat diperoleh konsumen dibandingkan dengan perdagangan konvensional tanpa harus bersusah payah pergi ke banyak tempat. Namun demikian, $e$ commerce juga memiliki kelemahan. Metode transaksi elektronik yang tidak mempertemukan pelaku usaha dan konsumen secara langsung serta tidak dapatnya konsumen melihat secara langsung barang yang dipesan berpotensi menimbulkan permasalahan yang merugikan konsumen.

Beragam kasus yang muncul berkaitan dengan pelaksanaan transaksi terutama faktor keamanan dalame-commerce ini tentu sangat merugikan konsumen. Padahal jaminan keamanan transaksi e-commerce sangat diperlukan untuk menumbuhkan kepercayaan konsumen penggunanya.Pengabaian terhadap hal tersebut akan mengakibatkan pergeseran terhadap falsafah efisiensi yang terkandung dalam transaksi e-commerce menuju ke arah ketidakpastian yang nantinya akan menghambat upaya pengembangan pranata $e$ commerce.

Permasalahan hukum serta pemecahan yang sudah dijelaskan di atas, sebenarnya tidak lain

\footnotetext{
${ }^{11}$ SudiknoMertokusumo,LocCit, Hal. 119
}

dimaksudkan sebagai upaya untuk memberikan perlindungan terhadap konsumen dalam transaksi $e$-commerce.

Masalah keamanan merupakan masalah penting dalam pemanfaatan media elektronik khususnya internet. Tanpa jaminan keamanan, maka para pelaku usaha akan enggan untuk memanfaatkan media ini. Untuk jaminan keamanan ini, hal yang perlu mendapatkan perhatian adalah masalah domisili perusahaan, sehingga apabila ada sengketa hukum, dapat diketahui dengan pasti kedudukan hukum dari perusahaan yang menawarkan produknya melalui media elektronik. Pada prinsipnya masalah perizinan, pendirian dan pendaftaran perusahaan sama dengan perusahaan pada umumnya, tunduk pada hukum di tempat di mana perusahaan didaftarkan.

Secara Nasional, pranata untuk memberikan perlindungan terhadap konsumen adalah UU No. 8 Tahun 1999 tentang Perlindungan Konsumen, namun UU perlindungan Konsumen ini secara khusus belum mengantisipasi perkembangan teknologi informasi di dalam pengaturannya. Dalam tataran internasional, telah dibuat kesepakatan-kesepakatan internasional yang secara khusus dapat digunakan untuk memberikan perlindungan terhadap konsumen dalam transaksi $e$-commerce.

Walaupun tidak secara khusus dibuat untuk memberikan perlindungan terhadap konsumen dalam transaksi e-commerce, seperti telah disebutkan di atas, PBB tepatnya komisi yang menangani Hukum Perdagangan Internasional telah menyetujui UNCITRAL Model Law on Electronic Commerce dengan resolusi 51/162 sebagai mandat untuk kemajuan terhadap harmonisasi dan unifikasi hukum perdagangan internasional demi kepentingan semua pihak, terutama pihakpihak dalam negara-negara berkembang.

Beberapa negara di dunia telah mengatur dalam perundang-undangan nasionalnya transaksi e-commerce ini diantaranya Filipina dengan Act No. 8792, Masyarakat Uni Eropa dengan disetujuinya 
Directive 2000/31/EC on Certain legal Aspect of Information Society Services, in Particular Electronic Commerce, in Internal Market atau Directive on Electronic Commerce oleh The European Parliament and The Council pada tanggal 8 Juni 2000, juga Singapura dengan Electronic Transaction Act 1998, Australia dengan Electronic Transaction Bill 1999, serta Amerika juga Malaysia. Khusus Singapura dan Australia digunakan model sejalan dengan apa yang direkomendasikan dalam UNCITRAL Model Law on Electronic Commerce. $^{12}$

Walaupun UNCITRAL Model Law on Electronic Commerce serta peraturan perundang-undangan yang telah digunakan di beberapa negara tersebut memang tidak secara khusus menyebutkan mengenai perlidungan hukum terhadap konsumen, substansi yang diatur dalam peraturanperaturan tersebut secara tidak langsung memberikan perlindungan terhadap para pihak yang melakukan transaksi elektronik $(e-$ commerce). Dengan ini berarti para konsumen yang menggunakan teknologi elektronik dalam transaksi bisnisnya dapat berlindung pada peraturan-peraturan ini.

Pranata dan Perlindungan Hukum terhadap Konsumen dalam Transaksi $E$ Commerce dalam tataran Nasional, Indonesia telah memiliki UU yang memberikan perlindungan terhadap hak kekayaan intelektual seperti hak Cipta, Paten dan Merk termasuk mengesahkan UU tentang Perlindungan Konsumen.Dalam tataran nasional usaha untuk memberikan perlindungan terhadap konsumen memang dinyatakan dengan diberlakukannya Undangundang No. 8 Tahun 1999 tentang Perlindungan Konsumen.

Selanjutnya dalam Penjelasan Undang-undang tersebut dijelaskan bahwa fenomena globalisasi dan perdagangan bebas yang didukung oleh kemajuan teknologi

${ }^{12}$ E.S. Wiradipradja dan D. Budhijanto, 2002, PerspektifHukumInternasionaltentang Cyber Law, dalamKantaatmadja, et al, Cyberlaw :SuatuPengantar, Elips 11.hal. 46 telekomunikasi dan informatika telah memperluas ruang gerak arus transaksi barang dan/atau jasa melintasi batas-batas wilayah suatu negara, sehingga barang dan/atau jasa yang ditawarkan bervariasi baik produksi luar negeri maupun produksi dalam negeri.

Tujuan perlindungan konsumen sebagaimana dinyatakan dalam Pasal 2 Undang-Undang Perlindungan konsumen ini adalah:

1. Meningkatkan kesadaran, kemampuan dan kemandirian konsumen untuk melindungi diri;

2. Mengangkat harkat dan martabat konsumen dengan cara menghindarkannya dari ekses negatif pemakaian barang dan/atau jasa;

3. Meningkatkan pemberdayaan konsumen dalam memilih, menentukan, dan menuntut hakhaknya sebagai konsumen;

4. Menciptakan sistem perlindungan konsumen yang mengandung unsur kepastian hukum dan keterbukaan informasi serta akses untuk mendapatkan informasi

5. Menumbuhkan kesadaran pelaku usaha mengenai pentingnya perlindungan konsumen sehingga tumbuh sikap yang jujur dan bertanggungjawab dalam berusaha;

6. meningkatkan kualitas barang dan/atau jasa yang menjamin kelangsungan usaha produksi barang dan/atau jasa, kesehatan, kenyamanan, keamanan, dan keselamatan konsumen ${ }^{13}$.

Perlu pula ditegaskan bahwa faktor utama yang menjadi kelemahan konsumen adalah tingkat kesadaran konsumen akan haknya masih rendah, yang terutama disebabkan oleh rendahnya pendidikan konsumen. Selain pengaturan dalam UU Perlindungan Konsumen, sebenarnya dalam tataran tertentu untuk melindungi konsumen dapat pula digunakan hukum pidana dalam

\footnotetext{
${ }^{13}$ Undang - Undang Nomor 8 Tahun 1999 tentang Perlindungan Konsumen.
} 
hal ini KUHP. Sebenarnya masih ada satu lagi pranata hukum yang dapat melindungi konsumen dalam transaksi e-commerce yakni dengan asuransi. Dari apa yang telah dipaparkan di atas, maka sudah sangat jelas bahwa demi kebutuhan perlindungan terhadap konsumen terutama konsumen yang melakukan transaksi bisnis dengan menggunakan teknologi elektronik $(e-$ commerce), maka urgensi untuk membuat legislasi yang mengatur mengenai hal ini sudah sangat tinggi. Hal ini disebabkan karena peraturan perundang-undangan yang ada terutama undang-undang yang mengatur mengenai perlindungan konsumen belum mengakomodasi kebutuhan tersebut.

Karakteristik yang berbeda dalam sistem perdagangan melalui teknologi elektronik tidak tercover dalam UU Perlindungan Konsumen tersebut. Untuk itu perlu dibuat peraturan hukum mengenai cyberlaw termasuk didalamnya tentang $e$ commerce agar hak-hak konsumen sebagai pengguna teknologi elektronik dalam proses perdagangan khususnya dalam melakukan transaksi e-commerce dapat terjamin.

\section{Tanggung Gugat Distributor dalam Hal Terjadi Wanprestasi}

Langkah pertama dalam hal terjadi wanprestasi yaitu melalui upaya hukum bagi transaksi e-commerce yang terjadi di Indonesia. Upaya konsumen untuk menuntut ganti rugi akibat kerugian yang terjadi dalam transaksi e-commerce dapat dilakukan melalui cara:

\section{a. Litigasi}

Dasar hukum untuk mengajukan gugatan di pengadilan terdapat dalam Pasal 38 ayat 1 UU ITE dan Pasal 45 ayat 1 UUPK $^{14}$. Dalam Pasal 38 ayat 1 UU ITE disebutkan bahwa ${ }^{15}$ :"Setiap orang dapat mengajukan gugatan terhadap pihak yang

\footnotetext{
${ }^{14}$ Undang - Undang Nomor 8 Tahun 1999 tentang Perlindungan Konsumen.

15 Undang - Undang Nomor 11 Tahun 2008 tentang Informasi dan Transaksi Elektronik.
}

menyelenggarakan Sistem Elektronik dan/atau menggunakan Teknologi Informasi yang menimbulkan kerugian".Sedangkan dalam Pasal 45 ayat 1 UUPK disebutkan bahwa"Setiap konsumen yang dirugikan bisa menggugat pelaku usaha melalui lembaga yang bertugas menyelesaikan sengketa antara konsumen dan pelaku usaha atau melalui peradilan yang berada di lingkungan peradilan umum".

b. Non Litigasi

Penyelesaian sengketa konsumen diluar pengadilan di selenggarakan untuk mencapai kesepakatan mengenai bentuk dan besarnya ganti rugi dan/atau mengenai tindakan tertentu untuk menjamin tidak akan terjadinya kembali kerugian yang diderita oleh konsumen (Pasal 47 UUPK) ${ }^{16}$.

Upaya hukum dalam hal transaksi ecommerce bersifat Internasional Masalah yang muncul dalam hal terjadi sengketa pada transaksi e-commerce yang bersifat internasional adalah menentukan hukum/pengadilan mana yang digunakan untuk menyelesaikan sengketa.Dalam Undang-Undang Informasi dan Transaksi Elektronik (UUITE), pengaturan mengenai transaksi e-commerce yang bersifat internasional terdapat dalam Pasal 18. ${ }^{17}$

Permasalahan lebih lanjut muncul ketika tidak dicantumkannya pilihan hukum dalam perjanjian e-commerce-nya, ada beberapa teori yang berkembang untuk menentukan hukum mana yang digunakan/berlaku, diantaranya:

1) Mail box theory (Teori Kotak Pos). Dalam hal transaksi e-commerce, maka hukum yang berlaku adalah hukum dimana pembeli mengirimkan pesanan melalui komputernya yang

\footnotetext{
${ }^{16}$ Undang - Undang Nomor 8 Tahun 1999 tentang Perlindungan Konsumen.

${ }^{17}$ Undang - Undang Nomor 11 Tahun 2008 tentang Informasi dan Transaksi Elektronik.
} 
dapat berarti hukum si customer. Untuk ini diperlukan konfirmasi dari merchant. Jadi perjanjian atau kontrak terjadi pada saat jawaban yang berisikan penerimaan tawaran tersebut dimasukkan ke dalam kotak pos (mail box).

2) Acceptance theory (Teori Penerimaan). Hukum yang berlaku adalah hukum dimana pesan dari pihak yang menerima tawaran tersebut disampaikan. Jadi hukumnya si merchant.

3) Proper Law of Contract. Hukum yang berlaku adalah hukum yang paling sering dipergunakan pada saat pembuatan perjanjian. Misalnya, bahasa yang dipakai adalah bahasa Indonesia, kemudian mata uang yang dipakai dalam transaksinya Rupiah, dan arbitrase yang dipakai menggunakan Badan Arbitrase Nasional Indonesia, maka yang menjadi pilihan hukumnya adalah hukum Indonesia.

4) The most characteristic connection. Hukum yang dipakai adalah hukum pihak yang paling banyak melakukan prestasi. Teori ini menjelaskan bahwa untuk menentukan suatu pilihan hukum yang akan digunakan adalah dengan mendasarkan terhadap prestasi, hal ini memberikan perlindungan terhadap pihak yang memberikan prestasi yang paling banyak untuk mencegah timbulnya kerugian terhadap pihak tersebut, sehingga hukum yang digunakan adalah hukum si pemberi prestasi terbanyak. ${ }^{18}$

Selain para pihak dapat menentukan hukum yang berlaku, para pihak juga dapat secara langsung menunjuk forum pengadilan, arbitrase, dan lembaga penyelesaian sengketa lainnya yang berwenang untuk

${ }^{18}$ http://hukumonline.com/klinik detail.asp. tanggal 24 Februari 2016 menyelesaikan sengketa diantara mereka (Pasal 18 ayat 4 UUITE) ${ }^{19}$.

Untuk menyelesaikan sengketa ecommerce yang bersifat internasional, sebaiknya menggunakan mekanisme ADR (Alternative Dispute Resolution).Alasannya adalah bahwa dengan menggunakan ADR maka para pihak tidak perlu dipusingkan dengan perbedaan sistem hukum, budaya dan bahasa. Dasar hukum ADR di Indonesia adalah Undang-undang No. 30 tahun 1999 tentang Arbitrase dan Alternatif Penyelesaian Sengketa. Pelaksanaan penyelesaian sengketa e-commerce di Indonesia belum sepenuhnya bersifat online, namun Undang-undang No. 30 tahun 1999 tentang Arbitrase dan Alternatif Penyelesaian Sengketa memberikan kemungkinan penyelesaian sengketa secara online dengan menggunakan e-mail.

Selalin upaya hukum yang dapat dilakukan oleh para pihak, juga dapat melalui prinsip tanggung gugat. Prinsip tanggung jawab mutlak adalah prinsip yang berlaku dalam hal terjadinya wanprestasi. Lemahnya kedudukan konsumen dalam transaksi ecommerce menjadikan tanggung jawab sepenuhnya berada ditangan pelaku usaha. Pelaku usaha akan bertanggungjawab penuh atas kegiatan usaha yang dilakukannya dalam transaksi e-commerce.

Dengan demikian, dalam transaksi ecommerce, pihak yang bertanggung jawab adalah pihak yang melakukan wanprestasi yang dalam hal ini dilakukan oleh pelaku usaha. Bentuk tanggungjawab yang diberikan oleh pelaku usaha adalah ganti rugi sesuai dengan besar kerugian yang diderita oleh konsumen. Apabila pelaku usaha tidak bertanggungjawab dalam hal melakukan wanprestasi pada transaksi e-commerce, maka konsumen dapat menempuh jalur hukum sesuai yang diatur dalam pasal 38 dan 39 UU

\footnotetext{
${ }^{19}$ Undang - Undang Nomor 11 Tahun 2008 tentang Informasi dan Transaksi Elektronik.
} 
ITE tentang penyelesaian sengketa dan melaporkannyakepihak yang berwajib.

Adapun bentuk-bentuk wanprestasi dalam perjanjian jual beli secara online adalah:

1. Ditinjau dari sisi pembeli (buyers), antara lain:

a. keterlambatan membayar Dalam hal ini kerlambatan pembayaran biasanya pihak yang sering melakukan hal keterlambatan tersebut adalah pembeli (buyers) ${ }^{20}$.

b. Tidak melakukan pembayaran Setiap pembeli biasanya berbeda-beda, artinya dalam melakukan transaksi secara online mereka mempunyai tujuan dan maksud sendiri-sendiri. Pada kenyataannya ada sebagian dari pembeli yang tidak melakukan kewajiban mereka secara baik.

c. Melakukan pembayaran namun tidak sesuai dengan apa yang diperjanjikan / disepakati Hal ini jarang terjadi dalam jual beli online.

2. Ditinjau dari sisi penjual (sellers), antara lain:

a. Mengirim barang, namun tidak sesuai dengan apa yang telah disepakati.

b. Mengirim barang namun terlambat.

Adapun beberapa bentuk wanprestasi dalam bisnis jual beli secara online. Melalui cyber space sesuai dengan bentuk-bentuk wanprestasi sebagaimana yang dikemukakan diatas, meliputi:

1. Tidak melakukan apa yang disanggupi akan dilakukannya.

2. Melaksanakan apa yang diperjanjikan, tetapi tidak sebagaimana diperjanjikan.

3. Melaksanakan apa yang diperjanjikan, tetapi terlambat..

4. Melaksanakan sesuatu yang menurut perjanjian tidak boleh dilaksanakan

Adapun tips-tips bagi penjual dalam berbisnis jual beli secara online agar terhindar dari bentuk wanprestasi, diantaranya:

${ }^{20}$ Zulfi Chairi, 2005, Aspek Hukum Perjanjian Jual Beli Melalui Internet, Fakultas Hukum Universitas Sumatera Utara, Medan.Hal. 34
1. Menyediakan berbagai macam varian barang yang diperjual belikan.

2. Mengadakan proses jual beli dengan perekrutan member dan lebih mengutamakan member tetap dalam prosesnya.

3. Mengadakan proses registrasi dalam melakukan transaksinya.

4. Memilih perbankan yang terpercaya dan profesional sebagai fasilitator pembayaran.

\section{E. KESIMPULAN}

Undang-Undang Perlindungan Konsumen (UUPK) dan Undang-Undang Informasi dan Transaksi Elektronik (UUITE) telah mampu memberikan perlindungan hukum yang memadai bagi konsumen dalam melakukan transaksi melalui e-commerce, perlindungan hukum tersebut terlihat dalam ketentuanketentuan UUPK dan UUITE dimana kedua peraturan tersebut telah mengatur mengenai penggunaan data pribadi konsumen, syarat sahnya suatu transaksi e-commerce, penggunaan CA (Certification Authority), dan mengatur mengenai perbuatan yang dilarang bagi pelaku usaha dalam memasarkan dan memproduksi barang dan jasa yang dapat dijadikan acuan bagi obyek dalam transaksi ecommerce.

Upaya hukum bagi konsumen dalam penyelesaian sengketa terdiri dari dua, yakni upaya hukum dalam hal transaksi ecommerce bersifat internasional yang penyelesaiannya menggunakan mekanisme ADR, dan upaya hukum dalam hal transaksi e-commerce yang terjadi di Indonesia yang dapat diselesaikan melalui dua jalur yakni jalur non-litigasi melalui Lembaga Swadaya Masyarakat (YLKI), Direktorat Perlindungan Konsumen Disperindag, Badan Penyelesaian Sengketa Konsumen (BPSK) dan pelaku usaha. Kemudian jalur kedua adalah melalui jalur litigasi/ pengadilan.

Wanprestasi dalam perjanjian jual beli secara online mempunyai banyak bentuk dan terkadang kita mengalaminya namun masih 
belum peka bahwa hal/kejadian tersebut dapat disebut suatu tindakan wanprestasi

\section{DAFTAR PUSTAKA}

\section{Buku :}

Chairi, Zulfi. 2005, Aspek Hukum Perjanjian Jual Beli Melalui Internet, Fakultas Hukum Universitas Sumatera Utara, Medan.

E.S. Wiradipradja dan D. Budhijanto, 2002, Perspektif Hukum Internasional tentang Cyber Law, dalam Kantaatmadja, et al, Cyberlaw :Suatu Pengantar.

Makarim, Edmon. 2000, Kompilasi Hukum Telematika, Grafindo Persada, Jakarta.

R.M. Suryodiningrat, 1979, Azas-Azas Hukum Perikatan, Tarsito, Bandung.

Khairandy, Ridwan. 2003, Itikad Baik dalam Kebebasan Berkontrak. Universitas Indonesia Fakultas Hukum Pasca Sarjana, Jakarta.

\section{Jurnal :}

Pramono, Nindyo, 2001, Revolusi Dunia Bisnis Indonesia Melalui E-commerce dan E-Bussines: Bagaimana solusi hukumnya, Artikel Dalam Jurnal Hukum No. 16 Vol. 8/2001.

Sanusi, Muhammad Arsyad. Transaksi Bisnis dalam E-comerce: Studi Tentang Permasalahan Hukum dan Solusinya, dalam Jurnal Hukum Ius Quia Iustum, No. 16 Vol. 8 Maret 2001: 10-29,

Sutrisno, Nandang. 2001, Cyberlaw: Problem dan Prospek Pengaturan Aktifitas Internet, dalam Jurnal Hukum Ius Quies Justum. No. 16 Vol. 8 Maret 2001:, Fakultas Hukum Universitas Islam Indonesia, Jogjakarta. Hal. 10-29

\section{Perundang-Undangan :}

Undang - Undang Nomor 8 Tahun 1999 tentang Perlindungan Konsumen.

Undang - Undang Nomor 11 Tahun 2008 tentang Informasi dan Transaksi Elektronik

\section{Website:}

http://hukumonline.com/klinik_detail.asp. tanggal 24 Februari 2016 